Franciszek Mróz

Uniwersytet Pedagogiczny w Krakowie, Polska - Pedagogical University of Krakow, Poland

\title{
Pokamedulski zespół klasztorny Pustelnia Złotego Lasu w Rytwianach - innowacyjny ośrodek w sektorze usług turystycznych województwa świętokrzyskiego
}

\section{Post-Camaldolese Monastery Complex Złoty Las Hermitage in Rytwiany - an Innovative Centre of Tourism Services Sector in the Świętokrzyskie Voivodeship (Poland)}

Streszczenie: Jednym z nowych trendów w turystyce religijnej na świecie są pobyty urlopowe i wakacyjne w klasztorach, pustelniach oraz domach rekolekcyjnych. Tak zwane wakacje i urlopy w klasztorach przeznaczone są dla osób uwikłanych w uzależnienia cywilizacyjne, które poszukują wyciszenia oraz odpoczynku od codziennych obowiązków. W Polsce do takich miejsc należy m.in. pokamedulski zespół klasztorny Pustelnia Złotego Lasu w Rytwianach, nazywany sanktuarium ciszy.Przeprowadzone badania pozwoliły na wskazanie głównych czynników, które stały się kluczem do sukcesu, czyli stałego rozwoju Pustelni i wzrastającej liczby podróżnych. Są to przede wszystkim:

- walory historyczne, kulturowe i architektoniczne Pustelni,

- dziedzictwo religijne ośrodka i duchowość monastyczna, odziedziczona tu po pustelnikach kamedułach,

- postawa duszpasterska i przedsiębiorcza dyrektora Pustelni, ks. kan. Wiesława Kowalewskiego - efektywnego i skutecznego lidera, jego cechy osobowe oraz umiejętność i rzetelność współpracy ze środowiskiem wewnętrznym i otoczeniem,

- bogata i unikatowa oferta terapii Relaksacyjno-Kontemplacyjnego Centrum Terapeutycznego „Pustelnia Złotego Lasu” SpeS (Salus per silentium),

- profesjonalna kadra do obsługi ruchu pielgrzymkowego i turystycznego,

- promocja ośrodka w środkach masowego przekazu,

- poszukiwanie i wprowadzanie nowych pomysłów, rozwiązań i projektów - innowacyjność oraz ekspansywność,

- rosnąca popularność urlopów i wakacji w klasztorach.

Abstract: One of the new trends in the religious tourism worldwide have been the holiday stays in monasteries, hermitages and retreat houses. The so-called holidays in monasteries are dedicated for people with civilisation addictions and those looking for peace and quiet as well as rest from everyday duties. 
In Poland, such places include e.g. the Post-Camaldolese Monastery Complex Złoty Las Hermitage in Rytwiany, dubbed the sanctuary of silence. The studies enabled to name the major success drivers of the continuous development of the Złoty Las Hermitage in Rytwiany and the growing tourist traffic in this centre. They include, first and foremost,

- the historical, cultural and architectural values of the Post-Camaldolese Monastery Complex,

- the religious heritage of the centre and the monastic spirituality, inherited from Camaldolese hermits here,

- the pastoral attitude and entrepreneurship of the Hermitage Director, canon priest Wiesław Kowalewski, an effective and efficient leader, his personal traits as well as the skills and reliability of cooperation with the inner community and the neighbourhood,

- rich and unique therapeutic offer of the Relaxation and Contemplation Therapy Centre "Złoty Las Hermitage" SpeS (Salus per silentium),

- professional staff serving the pilgrims' and tourists' traffic,

- centre promotion in mass media,

- looking for and introducing new ideas, solutions and projects, meaning innovation and expansion,

- growing popularity of "holidays in monasteries".

Słowa kluczowe: kameduli; pielgrzymowanie; pokamedulski zespół klasztorny Pustelnia Złotego Lasu w Rytwianach; przedsiębiorczość; turystyka religijna

Keywords: Camaldolese; entrepreneurship; pilgrimages; Post-Camaldolese Monastery Complex Złoty Las Hermitage in Rytwiany; religious tourism

Otrzymano: 10 stycznia 2020

Received: 10 January 2020

Zaakceptowano: 31 sierpnia 2020

Accepted: 31 August 2020

\section{Sugerowana cytacja/Suggested citation:}

Mróz, F. (2020). Pustelnia Złotego Lasu w Rytwianach - innowacyjny ośrodek w sektorze usług turystycznych województwa świętokrzyskiego. Przedsiębiorczość - Edukacja [Entrepreneurship Education], 16(2), 290-303. doi: 10.24917/20833296.162.23

\section{Wstęp}

Jednym z nowych trendów zachodzących w turystyce religijnej na świecie są pobyty urlopowe i wakacyjne w klasztorach, pustelniach oraz domach rekolekcyjnych. Tak zwane wakacje i urlopy w klasztorach przeznaczone są dla osób, które poszukują wyciszenia, odpoczynku od codziennych obowiązków i obciążeń zawodowych, a także dla osób wypalonych zawodowo, pogrążonych w depresji, uwikłanych w uzależnienia cywilizacyjne - infoholizmu, fonoholizmu, zakupoholizmu, pracoholizmu, hazardu, uzależnienia od jedzenia, gier, filmów, pornografii czy syndromu uzależnienia od zajętości (Addicted to Busyness Syndrome) (Griffiths, 2011). W wybranych krajach Europy Zachodniej (Hiszpania, Portugalia, Włochy) urlopy w klasztorach obejmują najczęściej szeroki pakiet „usług” oraz urozmaicony program pobytu: kursy kulinarne pozwalające na zgłębienie tajników kuchni zakonnej, uczestnictwo w stałych punktach dnia życia zakonników/zakonnic (wczesna pobudka, modlitwa, praca), spanie w klasztornej celi, skromne posiłki, a przede wszystkim czas na wyciszenie i modlitwę w samotności (Mróz, F., Mróz, Ł., 2013). Osoby wybierające wakacje lub urlopy w klasztorze mają możliwość przystąpienia 
do spowiedzi świętej, rozmowy z duszpasterzem, spaceru po klasztornych ogrodach i lekturę starych ksiąg w bibliotece klasztornej (Mróz, 2019).

Od wielu lat, również w Polsce, rośnie liczba klasztorów i obiektów poklasztornych oferujących weekendy, urlopy lub wakacje za murem klasztornym. Obecnie do najpopularniejszych tego typu miejsc należą: pokamedulski klasztor w Wigrach, klasztor kamedułów na Bielanach w Krakowie, klasztor oo. benedyktynów w Tyńcu, klasztor oo. marianów w Stoczku Klasztornym oraz pokamedulski zespół klasztorny Pustelnia Złotego Lasu w Rytwianach - nazywany często sanktuarium ciszy.

Przedmiotem badań jest pokamedulski zespół klasztorny Pustelnia Złotego Lasu w Rytwianach, w województwie świętokrzyskim, w gminie Rytwiany. Zespół ten uznawany jest za jeden $\mathrm{z}$ najcenniejszych obiektów zabytkowych w województwie świętokrzyskim, a rozporządzeniem Prezydenta Rzeczypospolitej Polskiej Andrzeja Dudy, z dnia 10 grudnia 2018 r. został uznany za pomnik historii. Celem badań, zasygnalizowanym w tytule pracy, było: zbadanie głównych działań przedsiębiorczych podejmowanych przez osoby opiekujące się i zarządzające Pustelnią Złotego Lasu; zbadanie ruchu turystycznego w ośrodku w latach 2004-2019 oraz wskazanie głównych czynników decydujących o rozwoju ośrodka. Zakres czasowy badań obejmuje lata: 2004-2019. Badania terenowe w Pustelni Złotego Lasu w Rytwianach prowadzone były w latach 2013-2019 i obejmowały podstawowe metody badawcze, tj. obserwacje, opis z autopsji, wywiady z ks. kan. Wiesławem Kowalewskim - dyrektorem Relaksacyjno-Kontemplacyjnego Centrum Terapeutycznego SPeS w Rytwianach ${ }^{1}$ oraz z pracownikami Pustelni, a także metodę analizy danych wtórnych (analiza dokumentów zastanych).

\section{Rys historyczny pokamedulskiego zespołu klasztornego Pustelnia Złotego Lasu w Rytwianach}

Zbadanie funkcjonowania Pustelni Złotego Lasu w Rytwianach i działań przedsiębiorczych podejmowanych w ośrodku wymagało uwzględnienia kontekstu historycznego. Konieczne jest zatem przedstawienie rysu historycznego ośrodka.

Historia Pustelni Złotego Lasu w Rytwianach rozpoczyna się w 1617 r. i nierozerwalnie wiąże się z Zakonem Kamedułów Pustelników z Kongregacji Kamedulskiej Monte Corona (Congregatio Eremitarum Camaldulensium Montis Coronae). W dniu 27 sierpnia 1617 r. kapituła generalna zakonu zatwierdziła fundację wojewody krakowskiego, Jana Magnusa Tęczyńskiego (1579-1637) i jego brata Gabriela Tęczyńskiego (1574-1617), wojewody lubelskiego (Kowalewski, Curyło, 2017). Bracia Tęczyńscy przez fundację zespołu klasztornego kamedułów w Rytwianach wpisali się w powszechny w okresie odnowy potrydenckiej trend fundacyjny w Polsce, popularny wśród magnatów i bogatej szlachty. Należy bowiem podkreślić, że fundacja wielkiej, murowanej świątyni lub też całego zespołu klasztornego była wyrazem troski fundatora o rozwój Królestwa Bożego na ziemi, podkreślała jego bogactwo oraz hojność, a także była najlepszym zadośćuczynieniem za popełnione grzechy (Mróz, 2010).

Erem kamedulski był drugim - po eremie Srebrnej Góry w Bielanach - na ziemiach Rzeczypospolitej. W 1621 r. do Rytwian przybyli kameduli z Bielan pod Krakowem

\footnotetext{
${ }^{1}$ Serdecznie dziękuję ks. kan. Wiesławowi Kowalewskiemu za udostępnienie danych pielgrzymkowych i turystycznych dotyczących Pustelni Złotego Lasu w Rytwianach, za liczne wywiady na temat funkcjonowania ośrodka, a także za gościnność podczas każdego pobytu w tym wyjątkowym miejscu.
} 
i w puszczy rytwiańskiej wybrali miejsce na budowę klasztoru i kościoła. Wybrane miejsce doskonale spełniało wymagania przepisów związanych z zakładaniem eremów, tj. było zwyczajowo oddalone o milę od siedzib ludzkich i znajdowało się na porośniętych lasem, częściowo splantowanych wzgórzach (Curyło, Kowalewski, 2017). Prace budowlane, według planów przywiezionych z Włoch, rozpoczęto 1 maja 1624 r., a kierowali nimi kolejni zakonnicy - o. Hieronim, o. Sylwan Boselli z Bergamo (przeor w latach 1625-1626) i o. Venanty da Subiaco (przeor w latach 1628-1629 i 1630-1632), który ozdobił świątynię malowidłami ściennymi i obrazami (Małkowicz, 2005; Urbanowicz, 1952; Zub, 1998).

Uroczystej konsekracji świątyni pw. Zwiastowania Panny Maryi oraz wchodzących w skład eremu budynków gospodarczych i eremitorium (objęte ścisłą klauzurą domki pustelników) dokonał w dniu 27 września 1637 r. sufragan krakowski, ks. bp Tomasz Oborski (1571-1645). On także, zachwycając się przestrzenią otaczającą erem, a zwłaszcza złocistą kolorystyką liści puszczy rytwiańskiej, nazwał konsekrowany zespół klasztorny kamedułów Eremus Silvae Aureae - Pustelnia Złotego Lasu. Kameduli „żyli w odosobnieniu - każdy mieszkał w oddzielnym domku. Głowa ogolona, broda zapuszczona, bose nogi w trepkach, biały habit - to zewnętrzny wygląd kameduły - przez Św. Romualda przepisany. Nie jadali mięsa - tylko w dzień Św. Benedykta, Św. Romualda i Zwiastowania N.M. Panny" (Siek, 1918: 59). W 1737 i 1741 r. erem dotknęły wielkie pożary, w trakcie których spłonęła biblioteka i część zabudowań klasztoru i dachu kościoła (Curyło, Kowalewski, 2017). Klasztor funkcjonował dzięki pracy zakonników przy wsparciu dobrodziejów - rodziny Opalińskich (od 1655 r.), Lubomirskich (od 1704 r.), Sieniawskich (od 1715 r.), Czartoryskich (od 1731 r.), ponownie Lubomirskich (od 1778 r.), Potockich (od 1815 r.), a w końcu Radziwiłłów (od 1897 r.) (Curyło, Kowalewski, 2017).

W roku 1819 władze rosyjskie oraz władze kościelne w Królestwie Polskim przeprowadziły kasatę 25 najbogatszych klasztorów męskich i 5 żeńskich - w tym także klasztoru kamedułów w Rytwianach. Projekt kasaty przygotowali minister Stanisław Kostka Potocki oraz Stanisław Staszic, a dekret supresyjny podpisał - pod naciskiem Potockiego - 17 kwietnia 1819 r. umierający i prawdopodobnie nie w pełni świadomy abp warszawski i prymas Królestwa Polskiego Franciszek Skarbek-Malczewski (1754-1819) (Kośka, 2016).

W 1825 r. ostatni czterej rytwiańscy kameduli przenieśli się do eremu na Bielanach pod Warszawą (Powidaj, 1881). Tym samym zakończyły się niemal dwustuletnia cicha praca, modlitwa, milczenie, post i pokuta zakonników w Pustelni Złotego Lasu (Pałęcki, 2012).

W 1860 r., staraniem Elżbiety z Branickich i Adama z hrabiów Potockich, do opuszczonego klasztoru w Rytwianach przybyli z Sandomierza franciszkanie reformaci (Zakon Braci Mniejszych Reformatów). Ich praca duszpasterska trwała jednak krótko - tylko do 1864 r., bowiem po upadku powstania styczniowego władze carskie w wyniku tzw. reformy klasztornej (monastyrskaja rieforma) zmusiły zakonników do opuszczenia Rytwian. Opuszczony przez kamedułów i franciszkanów reformatów zespół klasztorny w kolejnych dziesięcioleciach XIX w. i na początku XX w. popadł w ruinę (Zarewicz, 1871). W 1925 r. do klasztoru powrócili kameduli, jednak skala zniszczeń dawnego eremu była tak wielka (nie zachował się żaden z 16 domków pustelniczych), że kapituła zakonu zadecydowała przed zimą o opuszczeniu placówki przez zakonników. W 1935 r. kościół w Rytwianach został świątynią parafialną, a opiekę nad zniszczonym zespołem klasztornym sprawowali 
kolejni proboszczowie: ks. Wacław Siwiec (1935-1939), ks. Jan Fornalski (1939-1946), ks. Kazimierz Strzyż, 1946-1960) i ks. kan. Adam Łęcki (1960-1995) (Kowalewski, Curyło, Jelonek, 2017).

Nowy, przełomowy etap funkcjonowania Pustelni Złotego Lasu w Rytwianach rozpoczął się z początkiem nowego millenium. W dniu 9 czerwca 2001 r. bp Wacław Świerzawski, ówczesny ordynariusz diecezji sandomierski powołał w pokamedulskim zespole klasztornym w Rytwianach Diecezjalny Ośrodek Kultury i Edukacji „Źródło”. Dyrektorem ośrodka został mianowany ks. kan. Wiesław Kowalewski, któremu bp Świerzawski powierzył zadanie odbudowy zniszczonych zabudowań poklasztornych kamedułów oraz rozwój działalności kulturalnej i edukacyjnej w ośrodku. Konieczne jest podkreślenie, że w 2001 r. z dawnego zespół klasztornego kamedułów ocalał tylko kościół i fragment zabudowań klasztornych.

W kwietniu 2002 r. poklasztorny kościół pw. Wniebowzięcia NMP w Rytwianach został ustanowiony kościołem rektoralnym nowo powstałej parafii pw. św. Maksymiliana Marii Kolbego w centrum Rytwian, a rektorem świątyni został mianowany ks. kan. Wiesław Kowalewski. W 2002 r. zostało także powołane Stowarzyszenie Miłośników Pustelni Złotego Lasu, którego członkowie podjęli działania wspierające funkcjonowanie ośrodka „Źródło”. Wówczas także przedstawiono innowacyjny projekt utworzenia ośrodka współczesnej pustelni opartej na tradycji kamedulskiej - sanktuarium ciszy - otwartego dla osób spragnionych ciszy i uwikłanych w uzależnienia cywilizacyjne (Curyło, Kowalewski, 2017).

W dniu 15 sierpnia 2003 r. w Rytwianach odbyła się uroczystość poświęcenia kamienia węgielnego pod odbudowę Pustelni, której przewodniczył bp Andrzeja Dzięga. W pierwszym etap prac renowacyjnych, budowlanych i infrastrukturalnych doprowadzono do Pustelni drogę asfaltową i przyłącza sieci wodociągowej, gazowej, elektrycznej i telefonicznej, odwodniono fundamenty i elewację świątyni, odbudowano mur otaczający całe założenie klasztorne oraz szyję wjazdową, wyremontowano erem Tęczyńskiego oraz XVII-wieczną studnię, niemal od podstaw odbudowano południowe i zachodnie skrzydła zabudowań klasztornych i gospodarczych oraz dwa domki eremickie, a także doposażono obiekt w odpowiednie urządzenia i sprzęt. W odbudowanych budynkach poklasztornych na poddaszu powstały pokoje gościnne (ponad 60 miejsc noclegowych w celach jedno-, dwu-, trzy- i czteroosobowych z łazienkami), kaplica, na parterze - kuchnia i refektarz (restauracja kamedulska), sale terapeutyczne, pracownie zajęciowe oraz sale konferencyjne, zaś w piwnicach - sale odnowy biologicznej (Curyło, Kowalewski, 2017).

Poświęcenia odrestaurowanych zabudowań klasztornych dokonał 1 maja 2008 r. bp Andrzej Dzięga. Jednocześnie w Pustelni zostało otwarte nowoczesne Relaksacyjno-Kontemplacyjne Centrum Terapeutyczne SpeS (Salus per silentium - zdrowie przez ciszę) dla osób uwikłanych w uzależnienia cywilizacyjne. Prace remontowe, renowacyjne i konserwatorskie w pustelni prowadzone są do dzisiaj, a ich efekt budzi zachwyt i ogromne wrażenie wśród odwiedzających. W październiku 2011 r. otwarto ogrody klasztorne, odtworzone na powierzchni 2 ha w miejscu pierwotnego założenia i jak niegdyś pełniące jednocześnie funkcję rekreacyjną i użytkową. W 2011 r. otwarta została także Galeria Kamedulska, w której znajdują się archiwum, biblioteka, muzeum i wystawy obrazujące historię klasztoru kamedułów oraz najnowsze dzieje Pustelni.

W dniach 28-29 września 2013 r., z okazji 40-lecia serialu Czarne Chmury, w Pustelni Złotego Lasu zorganizowano benefis, w którym wzięli udział aktorzy serialu: Elżbieta 
Starostecka (w serialu jako Anna Ostrowska), Maciej Rayzacher (kapitan Knothe), Leonard Pietraszak (pułkownik Krzysztof Dowgird) i wielu innych. Ważnymi wydarzeniami religijnymi w Pustelni w ostatnim dziesięcioleciu były m.in. uroczyste wprowadzenie relikwii św. Jana Pawła II (11 kwietnia 2015 r.) oraz główne uroczystości Jubileuszu 400-lecia Pustelni Złotego Lasu (Kowalewski, Curyło, Jelonek, 2017).

\section{Czynniki warunkujące rozwój i podnoszenie atrakcyjności turystycznej} Pustelni Złotego Lasu w Rytwianach

Dyrektor Relaksacyjno-Kontemplacyjnego Centrum Terapeutycznego SPeS w Rytwianach podkreśla, że to „urokliwe miejsce stanowi swoiste sanktuarium ciszy, przepełnione milczeniem, samotnością i kontemplacją mnichów z kongregacji kamedułów, którzy tu, przez ponad 200 lat, toczyli ciche, okryte tajemnicą życie. Dziś, kiedy zakonników już nie ma w Rytwianach, wchodzimy w ich spuściznę, do miejsca pięknego i przepełnionego dawnym duchem modlitwy, do oazy, w której możemy naprawdę spotkać się sami z sobą, z innymi ludźmi i z Bogiem. W odbudowanych eremach można, z dala od hałaśliwego tłumu, spędzić czas jak pustelnicy, podejmując styl ich życia według starej benedyktyńskiej reguły, zatapiając się w modlitwie, podziwiając piękno barokowej architektury pośród złotoleśnej przyrody i oddając się medytacji nad pustelniczą sentencją memento mori (pamiętaj o śmierci)" (Kowalewski, 2006: 17).

O atrakcyjności turystycznej i pielgrzymkowej Pustelni Złotego Lasu w Rytwianach decydują przede wszystkim:

- walory historyczne, kulturowe i architektoniczne: barokowy kościół pw. Zwiastowania Najświętszej Maryi Panny w Rytwianach z malarstwem o. Venantego da Subiaco i Karola do Prevot (1670-1737) oraz stiukami włoskiego sztukatora Giovaniego Battisty Falcone (1600-1660) zaliczany jest do najcenniejszych obiektów sakralnych w Polsce i nazywany jest perłą barokowej architektury;

- dziedzictwo religijne ośrodka i duchowość monastyczna, odziedziczona tu po pustelnikach kamedułach;

- oferta terapii Relaksacyjno-Kontemplacyjnego Centrum Terapeutycznego „Pustelnia Złotego Lasu” SpeS - m.in. ergoterapia czyli terapia pracą, hortiterapia - terapia poprzez prace w ogrodzie, arteterapia - terapia sztuką, muzykoterapia, terapia ruchem (kinezyterapia i choreoterapia), silwoterapia - terapia poprzez las oraz terapia duchowa - pogłębianie życia wewnętrznego w duchu monastycyzmu kamedulskiego;

- walory krajobrazowe regionu, w którym znajduje się Pustelnia Złotego Lasu w Rytwianach oraz atrakcyjne położenie Pustelni na malowniczej polanie, w tzw. puszczy rytwiańskiej - w promieniu jednego kilometra od Pustelni brak zabudowań;

- walory przyrodnicze w pobliżu ośrodka - rozległe obszary leśne i pomnik przyrody Dąb Trzybratek;

- uznanie Pustelni Złotego Lasu za pomnik historii Rozporządzeniem Prezydenta Rzeczypospolitej Polskiej Andrzeja Dudy, z dnia 10 grudnia 2018 r.;

- oferta restauracyjna - kuchnia oparta na produktach ekologicznych oraz recepturach kamedulskich i benedyktyńskich (specjalności restauracji to kociołek kamedulski oraz pierogi) (www.pustelnia.com.pl/posilki-klasztorne);

- położenie Pustelni w sieci szlaków turystycznych prowadzących do atrakcyjnych turystycznie ośrodków na terenie województwa świętokrzyskiego - Sandomierza, 
Świętego Krzyża, Koprzywnicy, Kurozwęk, Opatowa, Pacanowa, Solca-Zdroju i Szydłowa;

- położenie Pustelni przy Europejskim Szlaku Dziedzictwa Kamedułów oraz przy szlaku turystyki serialowej - w 1973 r. pokamedulski zespół klasztorny w Rytwianach został wybrany jako plener do IV i X odcinka serialu Czarne chmury. Obecnie w Pustelni Złotego Lasu funkcjonuje muzeum serialu Czarne chmury;

- położenie Pustelni przy sieci szlaków pieszych, rowerowych i nordic walking;

- dobra dostępność komunikacyjna - Rytwiany położone są przy drodze wojewódzkiej nr 764 Staszów - Połaniec; 15 km od drogi krajowej nr 79; 90 km od Portu Lotniczego Rzeszów-Jasionka i 160 km od Międzynarodowego Portu Lotniczego im. Jana Pawła II Kraków-Balice.

Współcześni gospodarze Pustelni, podkreślając jej motto „Tu odnajdziesz święty spokój”, zapraszają osoby, które pragną w ciszy spojrzeć w głąb siebie, uporządkować swoje wnętrze i rozpocząć nową drogę życia.

Pewnego rodzaju potwierdzeniem wysokiej oceny funkcjonowania i atrakcyjności ośrodka są zapisy w Księdze gości Pustelni Złotego Lasu. Jako przykład warto zacytować dwa wybrane wpisy: „Zachwyceni, głęboko poruszeni, zaskoczeni, pełni szczerego szacunku, z podziwem i podziękowaniem za wielkie Dzieło, jakim jest Pustelnia z nadzieją na rychłe spotkanie - Andrzej S.” i „, Tu jest po prostu Bosko! Bogu dzięki za tak wspaniałe miejsce".

Centrum Terapeutyczne SpeS w Rytwianach oferuje pakiety pobytowe zarówno jednodniowe, jak i weekendowe oraz wielodniowe dla gości indywidualnych oraz grup pielgrzymkowych. W Pustelni organizowane są rekolekcje dla osób duchownych i świeckich: rekolekcje ciszy, rekolekcje z postem, rekolekcje połączone z wykonywaną pracą w nawiązaniu do realizowanego przez kamedułów życiowego motta Ora et labora, dni skupienia dla różnych grup zawodowych oraz dni skupienia dla par przygotowujących się do przyjęcia sakramentu małżeństwa (www.pustelnia.com.pl/rekolekcje).

Bogate są także oferta i program turnusów organizowanych w ośrodku: turnusu pustelniczego, terapeutycznego, oczyszczająco-odchudzającego, sportowego, plastycznego i muzycznego. Jest również możliwość skonfigurowania własnego turnusu oraz rozpoczęcie go i zakończenie w dowolnym dniu lub także skorzystanie z turnusu próbnego lub miniturnusu (turnus pełny trwa minimum $4 \mathrm{dni}$ ) (www.pustelnia.com.pl/turnusy-terapia/). Goście mogą wybrać również pobyt w jednym z dwóch odbudowanych pustelniczych domków z ogródkiem. W ciągu roku organizowane są także stałe turnusy: wielkanocny (od Wielkiego Czwartku do Poniedziałku Wielkanocnego), majowy (od 30 kwietnia do 3 maja), na Boże Ciało (od środy do niedzieli), odpustowy (na Wniebowzięcie NMP do lub od najbliższej uroczystości niedzieli), patriotyczny (obejmuje 11 listopada), świąteczny (święta Bożego Narodzenia) oraz noworoczny (od Sylwestra do Trzech Króli) (Kowalewski, Curyło, 2017).

Pustelnia Złotego Lasu w Rytwianach dysponuje profesjonalnym zapleczem i sprzętem do organizacji konferencji, seminariów, szkoleń, spotkań biznesowych i okolicznościowych, a także kameralnych uroczystości rodzinnych.

Przeprowadzone badania terenowe w Pustelni Złotego Lasu w Rytwianach pozwalają na wskazanie głównych czynników, które stały się kluczem do sukcesu, jakim jest stały rozwój ośrodka. Poza wspomnianymi już elementami, które decydują o atrakcyjności turystycznej i pielgrzymkowej Pustelni, są to przede wszystkim: 
- postawa duszpasterska i przedsiębiorcza oraz aktywność dyrektora Pustelni, ks. kan. Wiesława Kowalewskiego - efektywnego i skutecznego lidera, jego cechy osobowe (zainteresowanie działaniami i pracowitość, silna osobowość, wytrwałość i elastyczność w zakresie realizowania celów) oraz umiejętność i rzetelność współpracy ze środowiskiem wewnętrznym i otoczeniem (por. Zioło, 2016).

- bogata i unikatowa oferta terapii Relaksacyjno-Kontemplacyjnego Centrum Terapeutycznego „Pustelnia Złotego Lasu” SpeS;

- profesjonalna kadra do obsługi ruchu pielgrzymkowego i turystycznego;

- możliwość skorzystania z posługi kierownika duchowego lub opieki psychologa i terapeutów;

- promocja ośrodka w środkach masowego przekazu (w prasie, radiu, telewizji i internecie), działanie aktualizowanego portalu internetowego ośrodka oraz liczne książki i albumy na temat Pustelni Złotego Lasu;

- poszukiwanie i wprowadzanie nowych pomysłów, rozwiązań i projektów - innowacyjność oraz ekspansywność;

- stale ubogacany program duszpasterski ośrodka;

- stale ubogacana oferta pakietowa pobytu w ośrodku;

- stale ubogacana oferta kulturalna ośrodka, obejmująca koncerty, wernisaże, wieczory poezji;

- kompleksowa organizacja konferencji, seminariów, szkoleń i spotkań okolicznościowych;

- przyjazny stosunek władz państwowych, samorządowych i kościelnych (na szczeblu diecezjalnym);

- pozyskanie grupy Przyjaciół wspierających rozwój ośrodka;

- pozyskanie funduszy unijnych w ramach Zintegrowanego Programu Operacyjnego Rozwoju Regionalnego oraz Europejskiego Funduszu Rozwoju Regionalnego, a także dotacji z Ministerstwa Kultury i Dziedzictwa Narodowego;

- bardzo dobra informacja o dojeździe do ośrodka w przestrzeni turystycznej powiatu staszowskiego i połanieckiego (drogowskazy przy drodze krajowej nr 79 oraz drodze wojewódzkiej nr 764 Staszów - Połaniec);

- współczesne trendy w turystyce - dążenie do zdrowszego trybu życia przez właściwe odżywianie się, odrzucanie nałogów i uzależnień oraz aktywny tryb życia;

- rosnąca popularność urlopów i wakacji spędzanych w klasztorach.

Ruch turystyczny i pielgrzymkowy do Pustelni Złotego Lasu w Rytwianach w latach 2003-2019

Analiza ruchu turystycznego i pielgrzymkowego do Pustelni Złotego Lasu w Rytwianach została przeprowadzona dla okresu 2003-2019 na podstawie rejestracji osób odwiedzających ośrodek. Pracownicy Pustelni prowadzą dokładną rejestrację osób, które odwiedzają obiekt zarówno w grupach zorganizowanych, jak i indywidualnie. Rejestrowani są odwiedzający, którzy są oprowadzani przez przewodnika. W statystykach uwzględnieni są również uczestnicy większych uroczystości, rekolekcji ciszy, rekolekcji kapłańskich, uroczystości rodzinnych, a także odbywających się na terenie Pustelni konferencji, szkoleń i plenerów. Wyraźnie należy jednak podkreślić, że Pustelnia Złotego Lasu jest 
wyjątkowym sanktuarium ciszy. Tu odczuwa się obecność mnichów, którzy przez niemal dwa wieki modlili się, pracowali i zachowywali milczenie. Milczenie było bowiem jednym z głównych wymagań stawianych w Regule św. Benedykta i konstytucjach zgromadzenia: „Zakonnicy powinni zachować zawsze milczenie, szczególniej jednak w godzinach nocnych [...]” (Reguła św. Benedykta..., 1912). Święty Benedykt napominał, że „lepiej jest milczeć, niż mówić”, odwołując się tym samym do cytatów biblijnych: „Przy wielomówstwie nie unikniesz grzechu, a jeśli swe wargi będziesz oszczędzał, okażesz rozsądek” (Prz, 10, 19) (Hiżycki, 2018). Dlatego z uznaniem należy ocenić kierowanie Pustelnią Złotego Lasu w Rytwianach w zakresie obsługi ruchu turystycznego i pielgrzymkowego, aby nie przekroczona została granica ciszy i intymności tego miejsca.

W latach 2003-2011 (z wyjątkiem 2009 r.) zarejestrowano w Pustelni Złotego Lasu w Rytwianach stały i wyraźny wzrost ruchu turystyczno-pielgrzymkowego. W tym okresie liczba odwiedzających ośrodek wzrosła ponad trzynastokrotnie (w 2003 r. zarejestrowano 3174 osoby, natomiast w 2011 r. - 43461 osób). Od 2011 r. przez kolejne lata drugiej dekady XX w. do 2019 r. liczba odwiedzających wynosiła rocznie około 40000 (rycina 1). Rekordowym pod względem frekwencji odwiedzających Pustelnię Złotego Lasu w Rytwianach okazał się 2019 r., w którym w ośrodku zarejestrowano 50990 osób. Wpływ na ten znaczny wzrost liczby odwiedzających miało przede wszystkim wpisanie Pustelni na listę pomników historii (10 grudnia 2018 r.), a tym samym podniesienie rangi turystycznej tego obiektu.

Wśród odwiedzających ośrodek zdecydowanie dominują osoby o motywacji poznawczej (kulturowej) i religijno-poznawczej. Z każdym rokiem rośnie jednak liczba pielgrzymów, którzy pielgrzymują do ośrodka - a więc na pierwszy plan wysuwają motyw religijny.

Rycina 1. Rejestrowany ruch turystyczny i pielgrzymkowy w Pustelni Złotego Lasu w Rytwianach w latach 2003-2019

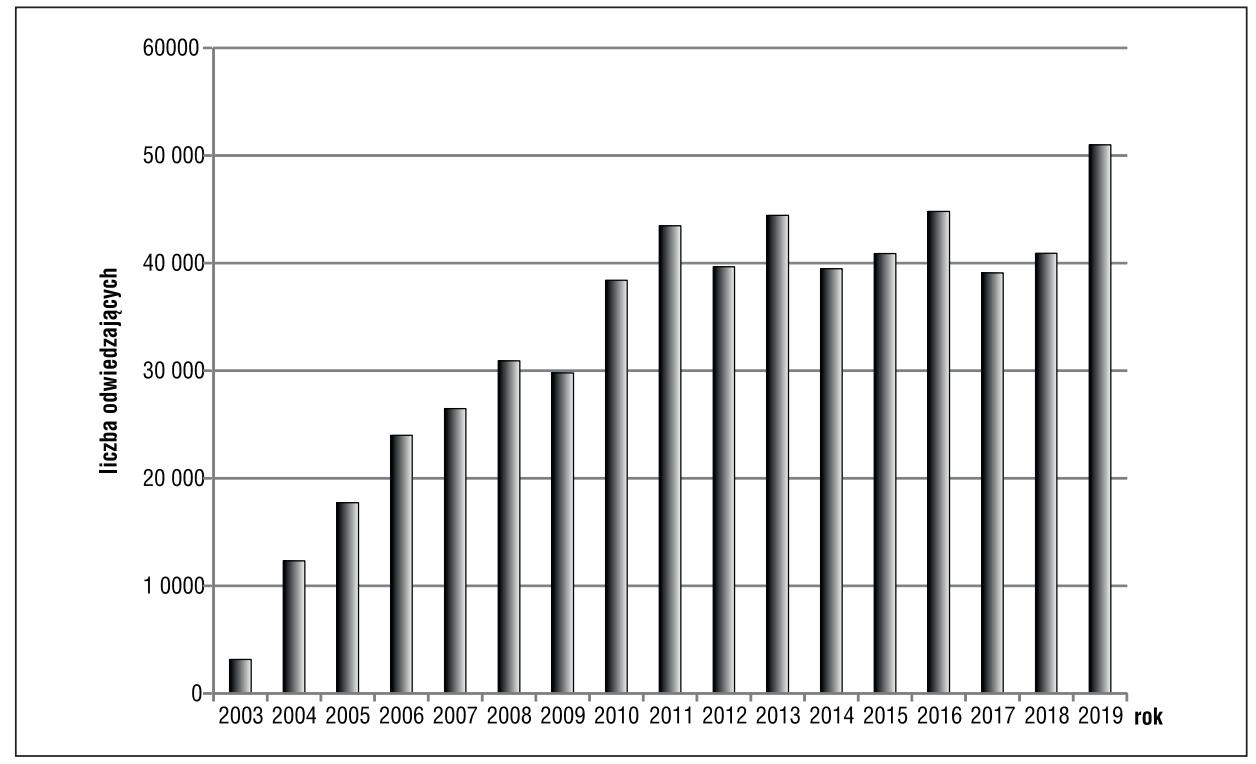

Źródło: Mróz (2020) na podstawie danych udostępnionych przez ks. kan. Wiesława Kowalewskiego, dyrektora Pustelni Złotego Lasu 
Najwięcej turystów i pielgrzymów przybywa do Pustelni podczas głównych uroczystości i wydarzeń kulturalno-religijnych, nawiązujących do kamedulskiej tradycji tzw. dni otwartej furty. Do takich wydarzeń należą przede wszystkim: Klasztorna Majówka (w weekend majowy), Europejski Festiwal Smaków Klasztornych (niedziela po uroczystości Bożego Ciała), Odpust Klasztorny Wniebowzięcia Najświętszej Maryi Panny (15 sierpnia), Kiermasz Jesienny „Leśna Apteka” (ostatnia niedziela września) oraz wspomnienie św. Jana Gwalberta, patrona leśników (niedziela po 12 lipca).

Największe znaczenie w programie duszpasterskim i kulturalno-religijnym ma Odpust Klasztorny związany z uroczystością Wniebowzięcia NMP. W ostatnich latach w odpuście tym uczestniczy około 8-10 tys. osób. Nieco mniejszą frekwencją cieszą się Klasztorna Majówka i Kiermasz Jesienny „Leśna Apteka” - ok. 4 tys. osób (w 2015 r.: 5250 osób; w 2017 r. - 3 200; w 2018 r. - 4 100).

Analizując kartogramy obrazujące zasięg przestrzenny oddziaływania Pustelni Złotego Lasu w Rytwianach (ryciny 3 i 4), należy stwierdzić, że w latach 2004-2016 uległ on znaczącym zmianom. W 2004 r. 47,2\% ogółu zarejestrowanych w ośrodku turystów (indywidulanych oraz $\mathrm{w}$ grupach zorganizowanych) pochodziło $\mathrm{z}$ województwa świętokrzyskiego. Znacznie mniejszy był udział województw: podkarpackiego (13,4\%), małopolskiego (10,6\%), mazowieckiego (9,6\%) i śląskiego (5,6\%). Zaskakujący - ze względu na bliską odległość od ośrodka - był udział województwa lubelskiego - zaledwie 3,2\%. W 2004 r. zarejestrowano w ośrodku tylko 12 turystów z województwa warmińsko-mazurskiego (0,2\%), 20 turystów z województwa podlaskiego (0,3\%) i 22 osoby z województwa opolskiego (0,4\%) (rycina 2). Najwięcej odwiedzających w 2004 r. Pustelnię Złotego

Rycina 2. Zarejestrowany ruch turystyczny i pielgrzymkowy do Pustelni Złotego Lasu w Rytwianach w $2004 \mathrm{r}$.

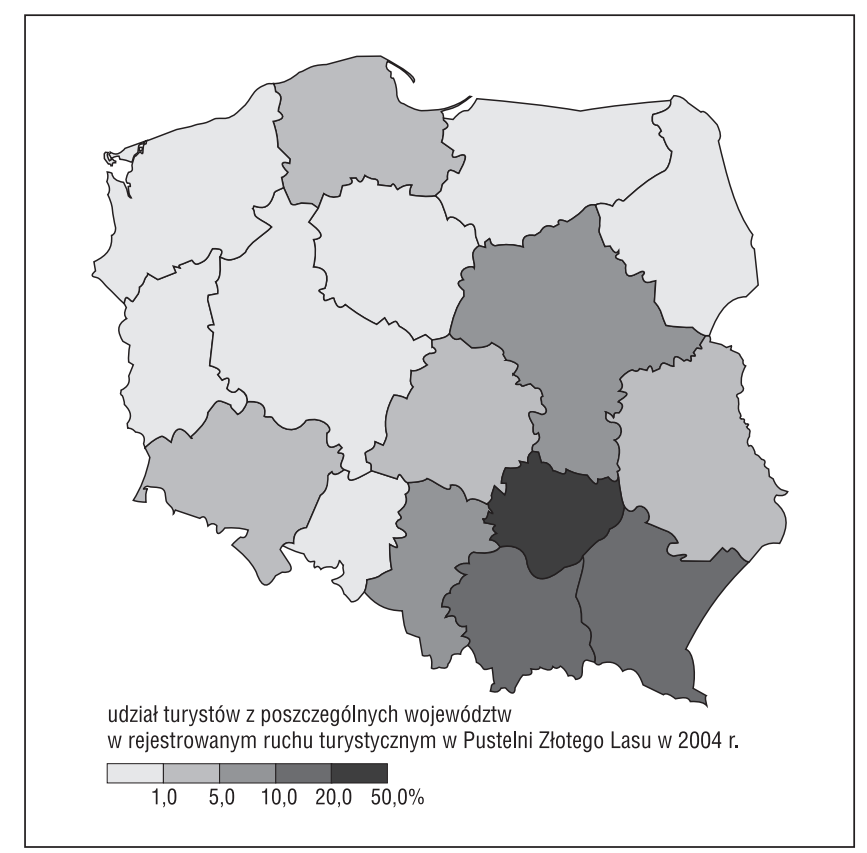

Źródło: Mróz (2020) na podstawie danych udostępnionych przez ks. kan. Wiesława Kowalewskiego, dyrektora Pustelni Złotego Lasu 
Lasu zarejestrowano z miejscowości położonych w promieniu $60 \mathrm{~km}$ od ośrodka - tj. ze Staszowa, z Połańca, Sandomierza, Buska-Zdroju i Tarnobrzega. Dużą grupę stanowili również odwiedzający z Kielc, Warszawy, Krakowa, Mielca, Ostrowca Świętokrzyskiego i Stalowej Woli.

W 2016 r. najwięcej turystów do Pustelni Złotego Lasu przybyło z województwa świętokrzyskiego - było to ponad 15 tys. osób. W porównaniu z 2004 r. udział turystów przybyłych z tegoż województwa wzrósł o niemal 10\% i wyniósł 56,9\%. W dalszej kolejności znalazły się województwa: podkarpackie (12,2\%), małopolskie $(9,3 \%)$, śląskie $(4,8 \%)$ i mazowieckie $(4,1 \%)$ - w każdym z tych pięciu województw, w odniesieniu do 2004 r., odnotowano jednak mniejszy udział w ogólnym ruchu turystycznym. Dane te wskazują, że w latach 2004-2016 r. nastąpił wyraźny wzrost koncentracji ruchu turystycznego do Pustelni Złotego Lasu turystów z województwa świętokrzyskiego. Najmniej odwiedzających w 2016 r. zarejestrowano z województw: lubuskiego (0,21\%), pomorskiego (0,25\%), zachodniopomorskiego (0,36\%), podlaskiego $(0,68 \%)$ i warmińsko-mazurskiego $(0,73 \%)$ (rycina 3$)$.

Należy jeszcze zwrócić uwagę na jeden element związany z dostępnością komunikacyjną ośrodka, a mający wpływ na ruch turystyczny do Rytwian. W listopadzie 2014 r. w Połańcu został otwarty most drogowy przez Wisłę, łączący województwo świętokrzyskie i podkarpackie. Dzięki temu nowemu połączeniu drogowemu znacząco wzrósł ruchu turystyczny z powiatów mieleckiego (województwo podkarpackie), dąbrowskiego oraz tarnowskiego (województwo małopolskie). I choć w 2016 r. liczba turystów z województwa podkarpackiego wzrosła do 3218 osób (z 767 osób w 2004 r.), a z województwa małopolskiego do 2453 osób (607 osób w 2004 r.) to jednak, jak już wspomniano, udział tych dwóch województw w ogólnym ruchu turystycznym do Pustelni Złotego Lasu był mniejszy niż w 2004 r.

Rycina 3. Zarejestrowany ruch turystyczny i pielgrzymkowy do Pustelni Złotego Lasu w Rytwianach w $2016 \mathrm{r}$.

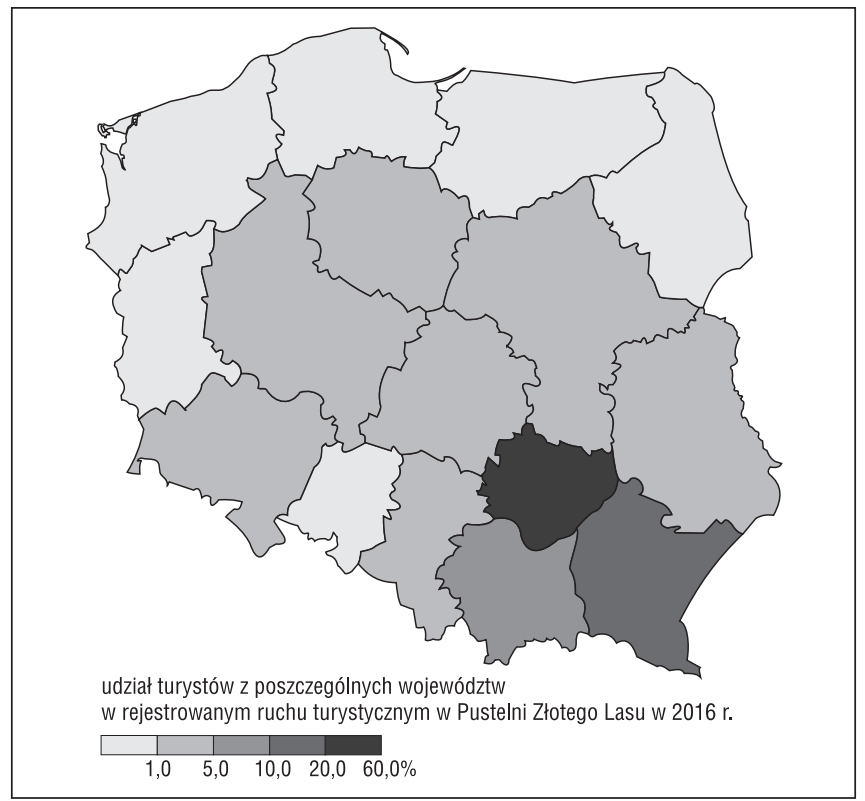

Źródło: Mróz (2020) na podstawie danych udostępnionych przez ks. kan. Wiesława Kowalewskiego, dyrektora Pustelni Złotego Lasu 
Rycina 4. Sezonowość ruchu turystycznego do Pustelni Złotego Lasu w Rytwianach w 2016 r.

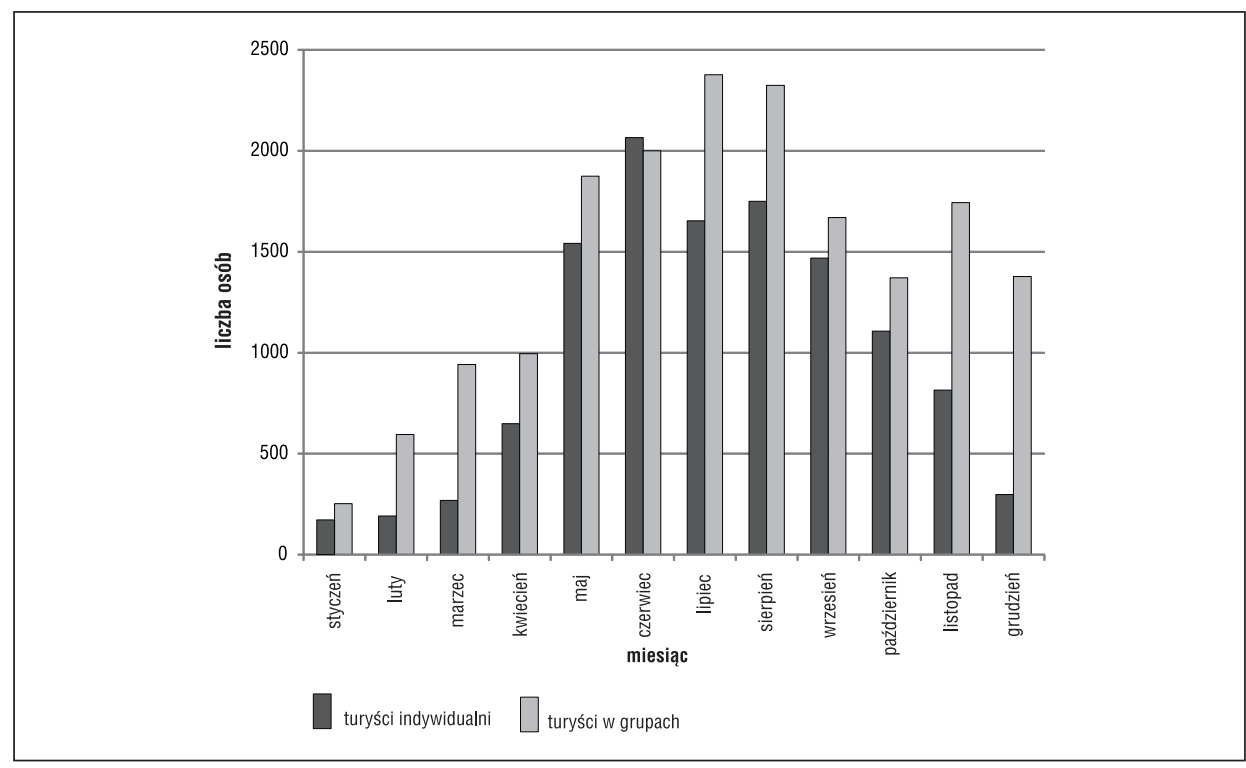

Źródło: Mróz (2020) na podstawie danych udostępnionych przez ks. kan. Wiesława Kowalewskiego, dyrektora Pustelni Złotego Lasu

Ruch turystyczny i pielgrzymkowy do ośrodka rozpoczyna się w Wielkanoc (przy czym pierwsze grupy przyjeżdżają w Niedzielę Palmową) i trwa do świąt Bożego Narodzenia. Najwięcej odwiedzających rejestruje się w wakacje - zwłaszcza w sierpniu, kiedy przypada główny Odpust Klasztorny, a także w maju i czerwcu (rycina 4).

Szczególnym okresem w najnowszej historii Pustelni Złotego Lasu w Rytwianach był 2017 r., w którym uroczyście obchodzono jubileusz 400-lecia Pustelni. Główne uroczystości jubileuszowe odbyły się w dniu 17 czerwca 2017 r. po przewodnictwem kard. Gerharda Müllera, prefekta Kongregacji Nauki i Wiary, a uczestniczyło w nich 8500 osób. W jubileuszowym Odpuście Klasztornym wzięło natomiast udział ponad 8200 osób. Należy podkreślić, że czas jubileuszu Penitencjaria Apostolska z upoważnienia Ojca Świętego Franciszka udzieliła pielgrzymom nawiedzającym Pustelnię Złotego Lasu łaski odpustu zupełnego.

\section{Zakończenie}

Salus per silentium oraz „Tu odnajdziesz święty spokój” to naczelne motta funkcjonowania Pustelni Złotego Lasu w Rytwianach. U podstaw wyjątkowej atrakcyjności tego ośrodka stoi cisza. Cisza, która pozwala zabieganemu, zapracowanemu i stale zatroskanemu człowiekowi XXI w. przekroczyć próg do przestrzeni, w której może on spotkać się sam ze sobą, a to jest kluczem do spotkania z Bogiem i drugim człowiekiem. Jak podkreśla ks. kan. Wiesław Kowalewski - dyrektor Pustelni Złotego Lasu, „»Żyć sam na sam z Bogiem i dla Boga samego « to motto kamedułów. Przez ponad 200 lat to »sam na sam « pozostawiło obecność Boga w każdym miejscu. Tą obecność czują wszyscy, którzy tu choć na chwilę, w ciszy chcą pozostawić swój obecny świat i przenieść się w przebogaty świat sacrum”. 
Przeprowadzone badania w Pustelni Złotego Lasu w Rytwianach pozwoliły na wskazanie głównych czynników, które stały się kluczem do sukcesu, jakim jest stały rozwój Pustelni i rosnący ruch turystyczny do ośrodka. Są to przede wszystkim: walory historyczne, kulturowe, architektoniczne oraz dziedzictwo religijne i duchowość monastyczna Pustelni, postawa duszpasterska i przedsiębiorcza dyrektora Pustelni, ks. kan. Wiesława Kowalewskiego, pracowników i przyjaciół Pustelni, bogata i unikatowa oferta terapii Relaksacyjno-Kontemplacyjnego Centrum Terapeutycznego „Pustelnia Złotego Lasu” SpeS, rosnąca popularność urlopów i wakacji w klasztorach, promocja ośrodka w środkach masowego przekazu. Wykonane w ostatnim dwudziestoleciu prace renowacyjne, budowlane i konserwatorskie w przestrzeni pokamedulskiego zespołu klasztornego Pustelnia Złotego w Rytwianach doprowadziły do sukcesu, którym niewątpliwie jest odzyskany blask ośrodka i wpisanie go na listę pomników historii. Największym sukcesem gospodarzy ośrodka jest przede wszystkim to, że dzisiaj nadal i stale w tej niezwykłej przestrzeni ciszy wybrzmiewają duch, wiara, modlitwa i milczenie białych mnichów.

\section{Literatura}

References

Curyło, K., Kowalewski, W. (red.). (2017). Pustelnia Złotego Lasu w Rytwianach. 1617-2017. Przewodnik jubileuszowy. Rytwiany: Wydawnictwo Diecezjalne i Drukarnia w Sandomierzu.

Griffiths, M.D. (2011). Workaholism: A 21st century addiction. The Psychologist: Bulletin of the British Psychological Society, 24, 740-744.

Hiżycki, Sz. (2018). Milczenie w regułach monastycznych. W: R. Bednarczuk, M. Rokosz (red.), Fenomen milczenia w kulturze i języku. Materiały interdyscyplinarnego sympozjum poświęconego pamięci profesor Jolanty Rokoszowej zorganizowanego przez Wydział Filologiczny PAU. Kraków: Wydawnictwo Polskiej Akademii Umiejętności, 15-24.

Kośka, M. (2016). Dekret abpa Franciszka Skarbka-Malczewskiego z 17 IV 1819 r. w sprawie supresji klasztorów w Królestwie Polskim. Hereditas Monasteriorum, 8, 367-378.

Kowalewski, W. (2006). Przedmowa. W: W. Kowalewski (red.), Rytwiany. Pustelnia Złotego Lasu. Sandomierz: Wydawnictwo Diecezjalne i Drukarnia w Sandomierzu.

Kowalewski, W., Curyło, K., Jelonek, B. (red.). (2017). 400 lat Pustelni Złotego Lasu w Rytwianach. Rytwiany.

Małkowicz, A. (2005). Twórczość malarza-kameduły o. Wenantego z Subiaco w świetle najnowszych badań. Folia Historica Cracoviensia, 11, 117-132.

Mróz, F. (2019). Changes in religious tourism in Poland at the beginning of the 21st century. Turyzm, 29(2), 95-103.

Mróz, F. (2010). Geneza i funkcjonowanie sanktuariów Pańskich w Polsce w okresie odnowy potrydenckiej (XVI-XVIII w.). Peregrinus Cracoviensis, 21, 15-42.

Mróz, F., Mróz, Ł. (2013). Nowe trendy w turystyce religijnej. W: R. Pawlusiński (red.), Współczesne uwarunkowania i problemy rozwoju turystyki. Kraków: Instytut Geografii i Gospodarki Przestrzennej UJ, 105-119.

Pałęcki, W. J. (2012). Stużba Boża kamedułów polskich. Tradycje życia pustelniczego w świetle potrydenckiej liturgii rzymskiej (1605-1963). Lublin: Wydawnictwo KUL.

Powidaj, L. (1881). Rytwiany i ich dziedzice. Kraków: Czcionkami Drukarni „Czasu”.

Reguła św. Benedykta i Konstytucye Zgromadzenia Kamedułów-Pustelników Góry Koronnej przejrzane i potwierdzone przez Ojca św. Klemensa IX: podług wydania włoskiego w Rzymie R. P. 1670 przetłómaczone na język polski R. P. 1912. (1912). Kraków: Nakładem oo. Kamedułów na Bielanach.

Siek, W. (1918). Opis historyczny miasta i parafii Staszów. Radom. 
Urbanowicz, W. (1952). Malowidła Venantego da Subiaco w Rytwianach. (Z zagadnień związków architektury, rzeźby i malarstwa w sztuce polskiego Renesansu). Przeglad Artystyczny, 6, 29-39.

Zarewicz, L. (1871). Zakon kamedułów, jego fundacje i dziejowe wspomnienie w Polsce i Litwie. Oprac. według źródeł rękopiśmiennych archiwum OO. Kamedułów w Bielanach koło Krakowa. Kraków.

Zioło, Z. (2016). Przedsiębiorczość w rozwoju układów lokalnych. Przedsiębiorczość - Edukacja [Entrepreneurship - Education], 12, 6-17.

Zub, J. (1998). Rytwiany. Pustelnia kamedulska. Przewodnik po zabytkach sztuki. Tarnobrzeg: Wydawnictwo „Profil s.c.”

Franciszek Mróz, dr, urodzony w 1975 r. w Przeworsku, geograf społeczno-ekonomiczny, pracownik naukowo-dydaktyczny (adiunkt) w Katedrze Turystyki i Badań Regionalnych Instytutu Geografii Uniwersytetu Pedagogicznego w Krakowie. Wykładowca w Uniwersytecie Papieskim Jana Pawła II w Krakowie. Konsultant w Radzie ds. Migracji, Turystyki i Pielgrzymek Konferencji Episkopatu Polski. Członek Archicofradía Universal del Apóstol Santiago. Instruktor krajoznawstwa Polski. Obecnie jego zainteresowania badawcze koncentrują się m.in. wokół zagadnień związanych z pielgrzymowaniem, turystyką religijną i turystyką kulturową w Polsce, genezą i funkcjonowaniem ośrodków pielgrzymkowych w Europie, a także europejskimi szlakami kulturowymi ze szczególnym uwzględnieniem Camino de Santiago - Drogi św. Jakuba. Jest autorem ponad 110 publikacji naukowych, 2 monografii, ponad 60 publikacji popularno-naukowych, redaktorem 14 prac zbiorowych, współautorem 1 monografii oraz 2 przewodników z tego zakresu. Od 2008 r. jest współorganizatorem corocznych międzynarodowych konferencji naukowych poświęconych problematyce historii i funkcjonowania Drogi św. Jakuba w Europie. Jest szczęśliwym mężem i ojcem trojga wspaniałych dzieci: Piotra (19 lat), Michała (17 lat) i Anny (12 lat).

Franciszek Mróz, PhD, socio-economic geographer born in 1975 in Przeworsk, an academic (assistant professor) in the Department of Tourism and Regional Research of the Institute of Geography at the Pedagogical University of Krakow. Lecturer at the Pontifical University of John Paul II in Krakow. Consultant in the Migration, Tourism and Pilgrimage Council of the Polish Episcopal Conference. Member of Archicofradía Universal del Apóstol Santiago. Instructor of Polish cultural and regional studies. His present research interests are concentrated on, for example, issues related to pilgrimages, religious and cultural tourism in Poland, origins and functioning of pilgrimage centres in Europe, and European cultural routes, especially Camino de Santiago - the Way of St. James. He is the author of more than 110 publications, 2 monographs, more than 60 popular science publications, as well as an editor of 14 collaborative publications, co-author of 1 monograph and 2 guides. Since 2008, he has been the co-organiser of annual international scientific conferences devoted to the history and functioning of the Way of St. James in Europe. He is also a happy husband and the father of three wonderful kids: Piotr (19), Michał (17) and Anna (12).

ORCID: https://orcid.org/0000-0001-6380-387X

\section{Adres/Address:}

Uniwersytet Pedagogiczny im. Komisji Edukacji Narodowej w Krakowie

Instytut Geografii

Katedra Turystyki i Badań Regionalnych

ul. Podchorążych 2

30-084 Kraków, Poland

e-mail: franciszek.mroz@up.krakow.pl 